\title{
City maps: Dreams, Art, Cartography, Planning
}

\author{
Cosimo Palagiano*
}

Emeritus Professor at the Sapienza Università di Roma

Corresponding member of the Accademia Nazionale dei Lincei

IGU Chair of the IGU-ICA Joint Commission on Toponymy

Sapienza Università di Roma

cosimo.palagiano@uniroma1.it

*Corresponding author

\begin{abstract}
The importance of cities becomes ever greater not only for the modification of the landscape, but also for the distribution of social classes. Poets, philosophers and artists have imagined ideal cities that could satisfy the need for a good quality of life for citizens.

Since the most ancient civilizations poets and philosophers have imagined ideal cities, with road plots corresponding to the various social classes. In the final text I will describe some examples of ideal cities presented by Homer, especially in the description of the shield of Achilles, from Plato in the description of his Atlantis, etc.

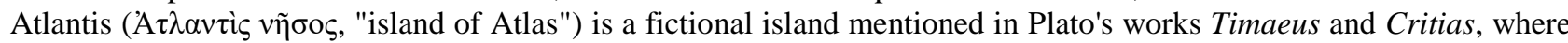
Plato represents the ideal state imagined in The Republic

The city depicted in the Homeric shield of Achilles, as an ideal form, centred and circular, competes with the other city scheme based on an orthogonal plan and linear structures. The form of the Homeric city has exerted a paradigmatic function for other cities in Greece and Rome.

Among the best known images of ideal cities I will consider the Città del Sole (City of the Sun) by Tommaso

Campanella and Utopia by Thomas More.

There are many books of collection of paintings of cities (G Braun and F Hogenberg, 1966).The most complete and interesting is that of Caspar van Wittel or Gaspar van Wittel (1652 or 1653, Amersfoort - September 13, 1736, Rome). He was a Dutch painter who played a remarkable role in the development of the veduta. He is credited with turning city topography into a painterly specialism in Italian art (G Briganti, 1996).

A rich collection of maps of Rome in the books by Amato Pietro Frutaz.

The city "liquid dimension" represents the complexities and contradictions of civic communities increasingly characterized by fragmentation and social unease.
\end{abstract}

Keywords: Art, Cities, Cartography, Dreams, Planning

\section{An introduction. City maps}

The city and the urban population always take on greater importance in the current world. This is why I think that cartography must pay increasing attention to cities, to the road network, to odonomy, but above all to the quality of urban life, contrasting the static nature of the cartographic design. A term for defining the urban complexity is rhizomatic network. The term, very ambiguous, often recurs in the urban descriptions represented as open systems, always feasible, however and everywhere, where losing oneself acquires the meaning of a new discovery, of an unpredictable encounter (Salazar 2003; Careri 2006). The rhizomecity is a network that cannot be unrolled, it is extensible to infinity, without exterior or interior. In it the process of connection between nodes is also a continuous process of correction of the connections themselves, so that its structure changes at every moment, "and each time it could be travelled along different lines, encouraging contradictions: if each of its nodes can be connected with every other node of it, from every node we can reach every other node "(Eco 2007: 59-60). Obviously not all cities obey this system, but certainly, the systematic development of the centre and the periphery is dissolving into a polycentric structure, from which the quality of life in the different areas cannot be deduced.

From a historical point of view we can compare two or more city maps of different historical times to follow the physical evolution of the city. But the comparison must be carried out with caution, because the author of the map does not always faithfully report the situation of the city at a precise moment.

For the city of Rome an excellent collection of city maps are the three volumes of Frutaz, which present 
city maps from Roman times to the modern age. The publication, promoted by the Universal Exhibition Authority (E.U.R.), by the Municipality of Rome and by the State Poligrafic Institute, was to be published in 1942, on the occasion of the Twentieth Exposition which then did not take place due the second world war.

Resumed after the war, the project was completed by the archaeologist and historian from Aosta, Amato Pietro Frutaz (Torgnon, 1907-1980) who duplicated the number of plants in Rome taken into consideration, availing himself of the help of scholars and librarians Giorgio De Gregori and Niccolò Del Re. 245 are the plants examined and reproduced (actually they are 267, since some, for technical reasons, have been considered under the same number). The topography of the city of Rome, in the year 1962, had already been treated previously, in volume XXII, promoted by the National Institute of Roman Studies, under the title Topography and urban planning of Rome. The types of support of the Rome are many: plants from the marble of the Urbis Severiana form of the $3^{\text {rd }}$ century (the only topographic document of ancient Rome preserved in original, in 993 fragments, Plan I), to the two miniatures of Pietro del Massaio (1469 and 1471-'72) which are illustrations of codes containing the Geography by Ptolemy (Plants LXXXVII and LXXXVIII), the plant painted by Alessandro Strozzi in 1474 (Plant LXXXIX), to that painted on wood by Pieter Bruegel il Vecchio c. 1551 which reproduces scenes from the Sack of Rome (Plant XCIX), to the Grand Prospect of the Alma City of Rome, drawn and engraved on paper in 1765 by Giuseppe Vasi (Plant CLXXI). The last, in order of time, is the map of Rome by Vincenzo Visceglia, and, with urban and peripheral divisions established on September 13, 1961 (Plant CCXLV).

\section{Dreaming of an ideal city}

The city is from immemorial times the centre of religious, social and political life, so much so that it is protected by walls. We should therefore not be surprised if it has always assumed considerable importance in the collective imagination, starting with the first peoples. Distinguished poets and thinkers of the past have had an emblematic reference point in the city. Imagination and desire of an ideal city, not only the urbanistic point of view, but also the social one, as a place of perfect happiness for its inhabitants. There are few exceptions of cities symbolically defined as cities of evil and sin, like Babylon. "After seventy years, I will punish the king of Babylon and that people - says the Lord - for their crimes, will punish the land of the Chaldeans and reduce it to a perennial desolation" (Jeremiah 25:12). "I made you a snare and caught you, Babylon, without noticing. You were surprised and caught, because you made war on the Lord" (Jeremiah 51:24). Ultimately, all evil will be judged, as symbolized by Babylon's demise in Revelation 18:21: "The great city of Babylon will be thrown down, never to be found again". Yet Babylon was the site of one of the seven wonders of the ancient world, that is, of hanging gardens. But perhaps even these gardens were imaginary, since Herodotus himself does not describe them. Herodotus describes Babylon, its history and customs on many pages (I, 178-200). In the Middle Ages, the city of Babylon was considered an infernal city seat of sin, while Jerusalem was the city of the delights of Paradise. Giacomino da Verona (13th century) composed two works entitled De Babilonia civitate infernali and De Jerusalem celesti, with an eschatological flavor.

Since the most ancient civilizations poets and philosophers have imagined ideal cities, with road plots corresponding to the various social classes.

The city depicted in the Homeric shield of Achilles, as an ideal form, centred and circular, competes with the other city scheme based on an orthogonal plan and linear structures. The form of the Homeric city has exerted a paradigmatic function for other cities in Greece and Rome. According to Domenico Musti in the Shield of Achilles represented in the Iliad (III 468607 ) as the construction of the work of Hephaestus, we read "the right to the existence of the single polis; the recognition of the war function ...; the founding role of peace, always threatened and in danger ... The two Homeric poems thus become both inevitable components of the Greek conception of life " (Musti, 2008, p. 12)


Atlas") is a fictional island mentioned in Plato's works Timaeus and Critias, where Plato represents the ideal state imagined in The Republic. Both the primitive Athens, subdivided into areas to be cultivated and inhabited by peasants and artisans, and the rich and powerful Atlantis are in fact representations of the divine model outlined in the Timaeus, where the "historical" city is looked in its political and economic organization. In Timaeus' dialogue Plato writes (1727): "In front of that mouth that is called, as you Greek say, Columns of Heracles, there was an island. This island, then, was larger than Libya and Asia put together, and those who proceeded from it offered a ride to the other islands, and from the islands to the whole continent that was on the opposite side, around what is really sea. (24E-25A) [...] In later times, however, having experienced terrible earthquakes and floods, in the course of a day and night, the whole complex of your warriors suddenly sank beneath the earth, and the Island of Atlantis, similarly submerged by the sea, disappeared. (25C-D)" . Their decadence instead, ruled by natural cataclysms and, in the case of Atlantis, due to the greed of men, is a clear reminder of the corruption of states already described in the Republic. In analogy with the structure of the Timaeus, the second part of the Critias should have described the intermediate reality between logos and disorder, with a clear reference to the situation of the poleis in the decade between 360 and $350 \mathrm{BC}$, characterized by clashes between a center and the other for the control of commercial traffic. Also after the disappearance of the rival city, the Athens of the myth could have saved 
itself from the inexorable decline only by turning to laws inspired by Good (Adorno, 1978, pp. 213-215). However we also have the description of an ancient cities like Uruk in Mesopotamia, datable to ca. 3500$3000 \mathrm{BC}$ and corresponding to the current Warka (the Ptolemaic 'O $\rho \theta \alpha \gamma \alpha) 20 \mathrm{~km}$ from the Euphrates (Liverani 1998).

Today we find the most obvious Roman city in Pompeii, which lives in its dramatic reality (Musti, 2008, p. VII).

From the famous book by T. More, De optimo reipublicae statu, deque nova insula Utopia, every exposition of political and social ideal corresponding to certain ideas, ethical or religious, but unattainable is called utopia. The function of utopias, the first of which can be seen in the Platonic Politeia, is threefold. They point to ethical-political ideals that do not require institutional realization, but stand as ends to political action; they work as a working hypothesis, making the results that could be obtained through certain institutions totally different from those traditionally in force sensible; and finally they serve the critique of existing institutions, either by contrast, or by irony, etc. As the type of the latter is really the Utopia of More, as the type of positions of philosophical ideals is the Platonic Politeia. As the type of utopia "working hypothesis" (the formulation is by Sorel) is the Sociéte des Égaux of Babeuf next to many others. The most often taken literary forms to utopias are that of philosophical dialogue, of biography, of the adventurous novel and especially of the description of travel, robinsonade, etc.

In ancient times, in addition to Plato's Politeia, there are the writings of philosophical-religious utopia of Teopompo, Zeno, Evemero, Hecataeus, while Xenophon's Ciropedia can be used as a utopian representation of the ideal ruler. In the Middle Ages utopia was rejected on the margins of intellectual life, since all political theories and aspirations were organized within the framework of the juridical organization of the Empire, in that of the Church and in that of the heavenly city; in fact, heretical character assumed millenarianism and jejimism where utopian elements are strong.

The periods of maximum flowering of the utopias are, however, the 16th-17th and 18th-19th centuries.

Among the best known images of ideal cities I will consider the Utopia by Thomas More 1478-1535) and the Città del Sole (City of the Sun) by Tommaso Campanella (1568-1639). Utopia (Libellus vere aureus, nec minus salutaris quam festivus, de optimo rei publicae statu deque nova insula Utopia) is a work of fiction and socio-political satire by Thomas More, published in 1516 in Latin. The book depicts a fictional island society and its religious, social and political customs. The More's Utopia remembers the life in monasteries. Utopia is placed in the New World during the Amerigo Vespucci's voyages of discovery. The island contains 54 cities. Each city has not more 6000 households. There is no private property in Utopia, with goods being stored in warehouses and people requesting what they need. There are also no locks on the doors of the houses. The most important occupation on the island is agriculture. Husbands and wives are mutually subject In the City of the Sun no occupation is vile, and all are of equal dignity. The work of the Dominican philosopher is therefore a precious testimony of his passion and his hopes in front of a present reality with a tragic character. It is a work that perfectly records the ambitions of the most ready minds of Europe in the seventeenth century, faced with the irreversible decline of the feudal system (erased by the new economic processes that were about to give rise to capitalism); in the face of new geographical discoveries, before the scientific progress of the theories of Copernicus and Galilei. Workers who are required to expend greater effort, such as artisans and builders, receive more praise.

The citizens possess nothing, but everything is held in common, from food to houses, from the acquisition of knowledge to the exercise of activities, from honours to amusements, from women to children.

They live "like philosophers in common" because they are aware of the negative impact, not only on the social but also on the moral level, of an unequal distribution of goods.

Why did men create an ideal city? The reasons are many and are related to the different historical and cultural periods in which this ideal is perceived. In classical Greek antiquity, Plato describes the ideal city of democracy and perfection, even if it tells of a city that really existed many centuries before his time. Thomas More and Tommaso Campanella see a city without private property, with equality between men and women and with no occupation vile. In Thomas More there is also a sarcastic intent. For Thomas More the cities are thought of in the New World, at the time of Vespucci's discoveries.

From the depiction point of view in the humanistRenaissance age the ideal city is represented in the table the Ideal City preserved in Urbino in the National Gallery of the Marche.

\section{The vedute}

A happy combination of art, cartography and urban planning is that of the so-called views (in Italian vedute). In the days preceding the advent of photography, many artists and painters have dedicated themselves to representing cities not only in maps, but also in perspective, with oblique points of view, bringing out the artistic value of some buildings, such as churches, palaces of power and squares designed by famous artists. A fertile period of images of cities is that of the Grand Tour. Many travellers from different cultures come to Rome and Italy, but also to Greece, to admire the remains of classical antiquity. Often the sensitivity of Goethe or Stendhal or other travellers poets and prose writers have handed down memories that are not always objective, but certainly artistic of landscapes and cities. This is why the images of design and writings allow us to enter well into the historical and cultural context of different times. 
Many texts are available on city views both in plan and in perspective. For Rome I have already quoted the volumes of Frutaz. Very interesting are other texts that present many cities in the world. James Elliot (1987) reports some views to which I refer here, such as Strasbourg by Jan Jansson (p. 30-31). I would highlight the images of most important portrait, as that of Paris of 1739, designed by Michel Etienne Turgot (p. 58). Very beautiful is the view of Venice in 1500 , designed by Jacopo de' Barberi (p. 22-23). Another interesting map in prospective enclosed in the book by Elliott is the Depiction of Constantinople of Cristoforo Buondelmonte (1420), p. 17.

The horizontal vision of the city plants is useful for retracing the phases of urban development over time, but the perspective view follows the artistic and taste evolution of the different historical periods.

The same choice of cities to depict obeys the importance of these cities in different periods. This choice is also favoured by the beauty of the monuments and other buildings, according to the artistic taste of the painters.

The largest collection of city plans is the 3-volume collection by Braun G. and Hogenberg F. (1965), but the largest and most interesting collection of city plans and images designed by the author is Gaspar Van Wittel (Briganti 1996).

Concerning the toponymy of the streets, squares and monuments of the city, both the horizontal plans and the perspective views present an undeniable historical and cultural content as well as the frequent replacement of the names of the streets (odonomastic) with others by varying political conditions and cultural events of different times.

In fact the changes in the names of the streets, of the squares and the monuments of the city are much faster than the variations of the place names of the territory and of the cities themselves.

This is because political conditions change much faster than economic and social conditions.

First in Flanders artists such as Paul Bril painted vedute as early as the 16th century. In the 17th century Dutch painters depicted cities and landscapes in vedute which recalled the wealthy Dutch middle class, as for example the Johannes Vermeer's Veduta of Delft. The Ghent architect, Lieven Cruyl (1640-1720) the vedute during his residence in Rome in the late 17th century. Cruyl's drawings reproduce the topographical aspects of the urban landscape. By the mid-18th century, Venice became the centre of the vedutisti. Some of them depicted major capitals of Europe, e.g., Canaletto in London and his nephew Bernardo Bellotto in Dresden and Warsaw. One of the most famous painters was Gaspar van Wittel Van Wittel is one of the principal painters of topographical views known as vedute. He is credited with turning topography into a painterly specialism in Italian art. When van Wittel first arrived in Rome he drew 50 drawings illustrating the Dutch hydraulic engineer Cornelis Meyer's designs for restoring navigability to the River Tiber between Rome and Perugia. His first vedute also originated from his collaboration with Meyer, who used drawings by van Wittel to illustrate one of his tracts with a series of engraved Roman views. Van Wittel used some of these drawings for tempera and oil vedute dating from the early 1680s. His style of vedute was formed about 10 years later. His work developed from that of the Dutch Italianate painters, whose work incorporated Roman ruins and other Roman sights. Their paintings always placed architecture within the surrounding landscape. Van Wittel's approach was derived from this and as result his views show buildings from a distance. He showed large architectural complexes in an overall view. His work should therefore be seen as a mixture of landscape and urban architecture painting rather than simple vedute. It is possible that he relied on the aid of a optic camera in drawing his vedute. His compositional and perspective principles remained the same from the 1690s, only the subject matter changed. His work was very popular with travellers on their Grand Tour of Italy. Thomas Coke, the future 1st Earl of Leicester and builder of Holkham Hall, Norfolk, acquired at least seven vedute by van Wittel during his Grand Tour in the years 1715 and 1716. In 18thcentury in Italy Giovanni Paolo Pannini was the first veduta artist to depict the ruins. The Dutch painter Gaspar van Wittel (known in Italy as Vanvitelli) and others painted veduta esatta, i.e. exact vedute, with a topographically accurate depiction of a cityscape or monument with rare presence of men and animals Another artist, Hendrik Frans van Lint was one of the leading vedute painters in the first half of the 18th century. At the end of the 17th century and beginning of the 18th century, the Flemish painter Jan Frans van Bloemen anticipated developments during the 18th century, with vedute from the classically oriented Roman landscapes. He may have been influenced by the drawings of the Flemish draughtsman Lieven Cruyl who had produced a series of cityscapes of Rome in the 1660s. Van Wittel's approach was derived from this and as result his views show buildings from a distance. He showed large architectural complexes in an overall view. His work should therefore be seen as a mixture of landscape and urban architecture painting rather than simple vedute. It is possible that he relied on the aid of a camera obscura or optic camera in drawing his vedute Van Wittel is also considered to have influenced one of the major Italian vedutisti, the Venetian painter Canaletto. During his visit to Venice around 1697 he painted some views which may anticipate Canaletto in their perspective layout and in the angle in which the scene is portrayed, as the View of the Piazzetta from St Mark's Basin (exhibited in Doria Pamphilj Gallery in Rome) (Briganti, p. 243). His compositional and perspective principles remained the same from the 1690s, only the subject matter changed. His work was very popular with travellers on their Grand Tour of Italy.

A further development of the vedute, are the capricci (caprices) which included partly or completely imaginary elements The capricci are also known as vedute ideate or veduta di fantas. The capricci were introduced by the Pannini's veduta. Giambattista Piranesi was the foremost master of vedute ideate 
etchings, whose topographical series, Vedute di Roma, become famous and popular. In the later 19th century, the topographical accuracy of personal "impressions" of cityscapes announced the imminent advent of landscape photography. Some artists, such as Antonietta Brandeis, the Spanish painters Martín Rico y Ortega, Mariano Fortuny, Antonio Reyna Manescau and Rafael Senet and the Peruvian painter Federico del Campo favoured the large international market of city views of Venice. Often the same urban landscapes were painted several views with minimal variations for commercial purposes. The most active painters of such vedute were Federico del Campo and Reyna Manescau. Canaletto was an Italian painter of vedute and imaginary views (capricci) of Venice, Rome, and London. He further used the etching technique. From 1746 to 1756 he painted many vedute of London, and other sites as far north as Warwick Castle and Alnwick Castle. His highly success in England was due to the British merchant and connoisseur Joseph "Consul" Smith. A large collection of Canaletto's works was sold to King George III in 1762. Making use of the innovative rationalistic ideas of the Enlightenment of the optical camera, he was able to accurately represent all the elements of the landscape and in all moments of the day in the right light and in perspective. Many other artists began to use the optical camera for depicting their works.

\section{The liquid city}

The density finds the right of citizenship in the "liquid" dimension and faithfully represents the complexity and contradictions of civic communities increasingly characterized by fragmentation and social unrest. The advancement of research and the most sophisticated application experiments in urban planning suggest a new hermeneutics for density, no longer confined to a static conception of the condition and urban. In a cutlral moment in which strong reference patterns of the settlement phenomenology lack, inverted by the density of flux, it represents a decisive trump card to fully understand the functioning logic of urban space and outlining virtuous evolutionary horizons. The new disciplinary dimension consists in knowing how to see the city for rhizomatic networks able to make explicit the potential of new identity spaces and return mature relationships of meaning to the system of traditional and static centrality (Monardo 2010 p. 7).

The city of "liquid dimension" represents the complexities and contradictions of civic communities increasingly characterized by fragmentation and social unease. The more sophisticated application in urban planning show for density a new hermeneutics. In a cultural moment the "dynamic figure" of the settlement phenomenology, inverted by the "flow density", represents a decisive asset to get to know the logic of the urban space and to outline its virtuous horizons. The new mission consists in "knowing how to see" the city, explaining the potential of the new identity spaces. In the mid-to-late 1990s, Zygmunt Bauman (19 November 1925 - 9 January 2017) began to explore postmodernity and consumerism. It had changed from a society of producers into a society of consumers. According to Bauman, this change reversed Freud's "modern" trade-off, i.e., security was given up in exchange for more freedom, freedom to purchase, consume, and enjoy life. In his books in the 1990s Bauman wrote of this as being a shift from "modernity" to "post-modernity". His books have tried to avoid the confusion surrounding the term "postmodernity" by using the metaphors of "liquid" and "solid" modernity. In his books Bauman still writes of the same uncertainties that he portrayed in his writings on "solid" modernity. But in these books he writes of fears becoming more diffuse and harder to pin down. Bauman coined the term allosemitism to encompass both philo-Semitic and anti-Semitic attitudes towards Jews as the other. Bauman emphasizes the negative political effect of media have on voter's choice by denouncing them as 'trap' where people only 'see reflections of their own face'. An example of liquid city in the antiquity is Spina (Zamboni 2016). The ancient port of Spina, a city founded in the second half of the 6 th century $\mathrm{BC}$, communicates to us sequences of precariousness. The continuous incidents of fires, the renovations and the project variations that we perceive from the excavation stratigraphy reveal the settlement difficulties and the experiments in the building field through which its inhabitants tried to tame a difficult landscape. And perhaps also the political and social relations between the various components of the surveyed, if after just three centuries the city disappears forever under the waters of the lagoon

\section{Conclusions}

The city maps could be considered in the great theme of cartography for : (1) the design of the streets, which can correspond to the different socio-economic classes. Much for than the general maps they present the inhabitants' life and then they can give an answer to the criticism to the general maps, which are static because they do not consider the people, the monuments, the history, etc.

\section{References}

Adorno F. (1978), Introduzione a Platone, Bari, Laterza.

Briganti G. (1996), Gaspar van Vittel. Nuova edizione a cura di Laura Laureati e Ludovica Trezzani, Milano, Electa.

Braun G. and Hogenberg F.(1965), Civitates orbis terrarum, 1572-1618. Introduction of R. A. Skelton, 3 vols. (MCMLXV) . Amsterdam, Theatrum Orbis Terrarum Publishing Company LTD.

Careri, F. (2006), Walkscapes. Camminare come pratica estetica. Torino: Einaudi.

Dalley, S. (2013). The Mystery of the Hanging Garden of Babylon: an elusive World Wonder traced. Oxford University Press.

Eco, U. (2007). Dall'albero al labirinto. Studi storici sul segno e l'interpretazione. Milano, Bompani. 
Elliott James (1987). The City in Maps. Urban mapping to 1900. London, The British Library Board. Goss J. (1995). 60 vedute di città europee fra il XVI e il XVII secolo. Da "Civitates Orbis Terrarum di Georg Braun e Frans Hogenberg (Transl. By Piero Pieroni), Milano, Idealibri. Original Title: The City Maps of Europe, London, Studio Editions Ltd., 1991.

Liverani M. 1998. Uruk. La prima città. Bari, Laterza.

Monardo B. ed. (2010). La città liquida. Nuove dimensioni di densità in urbanistica, Santarcangelo di Romagna, Maggioli

Musti D. (2008). Lo scudo d'Achille. Idee e forme di città nel modo antico. Con appendici di Gianfranco Mosconi e Marco Santucci, Roma-Bari, Laterza.

Salazar R. (2003). The labyrinth of the city. Ciencia Ergo Sum, 10, 1, pp. 5-17

Zamboni L. (2016). Spina città liquida. Gli scavi 19771981 nell'abitato e i materiali tardo-arcaici e classici. Zürcher Archäologische Forschungen. Band 3. Herausgegeben von Christoph Reusser. Verlag Marie Leidorf GmbH. Rahden/West 